\title{
PERAN SISTEM INFORMASI MANAJEMEN (SIM) \\ DALAM PENGAMBILAN KEPUTUSAN
}

\author{
Meriska Hamni \\ Jurusan Sistem Informasi, Fakultas Sains Dan Teknologi, \\ UINSU \\ Email : meriskarika@gmail.com
}

\begin{abstract}
Information systems need to make sensible decisions, so it is really important to understand both knowing the problem and choosing a solution. More detailed information can make better decisions. Information quality depends on (three) things, namely information must be clear (accurate), time axis and correlation (correlation). Elements that must be considered in decision making include: the decision to determine the solution Questions about the calculation of factors that cannot be known beforehand Events beyond human control (uncontrollable events) and are used during evaluating or measuring the results of decisions.
\end{abstract}

Key words: Culture, Social, Economy, decision, information system.

\begin{abstract}
Abstrak
Sistem informasi perlu membuat keputusan yang masuk akal, jadi Perlu Pahami masalahnya dan pemahaman tentang memilih solusi. Informasi lebih detail dapat menghasilkan keputusan yang lebih baik. Kualitas Informasi bergantung pada (tiga) hal, yaitu informasi harus jelas (akurat), sumbu waktu dan korelasi (korelasi). Elemen yang harus diperhatikan dalam pengambilan keputusan antara lain: keputusan untuk menentukan solusinya Pertanyaan tentang perhitungan faktor yang tidak dapat diketahui sebelumnya Peristiwa di luar kendali manusia (peristiwa tak terkendali) dan digunakan selama Mengevaluasi atau mengukur hasil keputusan.
\end{abstract}

Kata kunci : Budaya, Sosial, Ekonomi,keputusan, sistem informasi 


\section{PENDAHULUAN}

Sekarang,informasi dipandang sebagai hal yang vital dalam semua bidang kehidupan, seperti pakaian, makanan, dan tempat tinggal. Informasi dalam jumlah besar. memiliki Dapat mengguncang semua bidang kehidupan masyarakat, termasuk kawasan ini ekonomi, sosial dan budaya, serta pengetahuan dan teknologi.

Dengan berkembangnya pengetahuan dan teknologikomputer, konsep dan gaya hidup masyarakat Indonesia telah mengalami banyak perubahanaktivitas. Kecanggihan informasi mengantarkan dunia baru pada pembangunan di berbagai sektor, namun kemajuan tersebut tidak sejalan dengan sumber daya manusia (SDM) yang masih rendah pada menentukan pencapaian misi IAEA.

Informasi Data adalah semua jenis korespondensi yang mampu menambah pengaturan dan informasi yang berguna bagi penerima laporan hal itu seperti udara yang berhembus melalui suatu organisasi. Fakta ilustratif berfungsi sebagai motivasi laporanrealitas peristiwa tertentu. Diblokir. Data masih dalam keadaan mentah, tidak dapat memberi tahu kita apa pun. Alhasil, harus diproses lebih lanjut. Data diolah dengan menggunakan contoh buat membentuk liputan. Sistem liputan sesungguhnya merupakan Sebuah subsistem bagian kecil dari gambaran yang lebih besar. Konstruksi dan pengoperasian sistem pelapisan memerlukan penggunaan sistem atau subsistem lainnya. alat cakupan adalah sistem kedua setelah subsistem tertentu organisasi. Fungsionalitas yang konsisten dengan subsistem lain bergantung sepenuhnya pada peran organisasi. Subsistem biasanya dijelaskan dalam aktivitas dan disinkronkan menurut organisasi dengan bantuan departemen berpemilik.

Fungsi sistem informasi adalah untuk mengontrol dan mengatur kegiatan subsistemsubsistem dalam organisasi untuk mendukung organisasi dalam mencapai tujuannya. Setiap anggota organisasi perlu menetapkan cakupan demi bagian sesuai dengan pekerjaan mereka, dan sistem cakupan akan mengoordinasikan kebutuhan sesuai dengan masing-masing individu. 
Pendekatan sistem sangat bergantung pada sinkronisasi ini. Dalam kesehariannya, sistem pertanggungan akhir dimaksudkan untuk menyediakan kebutuhan dasar baik bagi mereka yang memiliki tingkat ekonomi dan pendidikan rendah maupun individu dengan tingkat ekonomi dan pendidikan tinggi di semua bidang masyarakat. Semakin besar kebutuhan seseorang akan informasi, maka semakin tinggi pula status ekonomi dan pendidikannya. Sistem fakta yang bagus. Untuk membuat keputusan yang logis, Anda perlu memahami situasi dan mengetahui solusi lain. Anda dapat membuat pilihan yang lebih cerdas dengan lebih banyak informasi.

\section{STUDI LITERATUR}

Metode Studi literatur dalam artikel ilmiah ini adalah dengan memperoleh beberapa referensi atau informasi dari artikel, artikel, jurnal, artikel dan informasi yang berkaitan dengan internet, serta mendiskusikan pentingnya sistem informasi manajemen (SIM) dalam pengambilan keputusan. Saring berdasarkan fakta dan tentukan setiap informasi yang dicatat oleh penulis.

\section{PENGERTIAN SISTEM INFORMASI MANAJEMEN}

Untuk menjalankan tugas sehari-hari, sebuah organisasi melakukan transaksi yang mesti diproses. Faktor gaji, serta penjualan dan pembayaran yang terlalu tinggi, semuanya harus dipertimbangkan. Ini dan operasi lainnya adalah semua bentuk pemrosesan data yang mematuhi sekumpulan kriteria. Sistem informasi manajemen lebih dari sekedar sistem pemrosesan data, meskipun komputer sangat penting untuk berbagai jenis pekerjaan pemrosesan data. Komputer digunakan untuk menyediakan data untuk manajemen dan pengambilan keputusan dalam sistem pemrosesan informasi berbasis komputer.

Sistem Informasi Manajemen adalah sistem manusia / mesin terintegrasi untuk menampilkan informasi yang mendukung operasi, manajemen, dan fungsi pengambilan keputusan.

Perangkat keras komputer, manual prosedur, model manajemen dan keputusan, dan database 
semuanya digunakan dalam sistem ini.

\section{PERKEMBANGAN \\ KONSEPSISTEM \\ INFORMASI MANAJEMEN}

Sebelum

penggunaan

komputer, terdapat diskusi tentang sistem informasi untuk membantu manajemen dan pengambilan keputusan. Penerapan sistem informasi di tempat kerja dapat membantu mewujudkan visinya. Akuntansi manajemen, ilmu manajemen, teori manajemen, dan pemrosesan komputer semuanya telah maju secara ilmiah, memungkinkan konsep SIM mencapai keadaan saat ini. Apabila konsep SIM dipandang sebagai perluasan mendasar dari akuntansi manajemen yang meliputi ide dan prosedur dari pendekatan ilmu manajemen, teori perilaku dan pengambilan keputusan manajemen, dan kapabilitas komputer, maka konsep SIM menjadi lengkap.

Ilmu manajemen adalah penerapan prinsip ilmiah dan alat analisis kuantitatif untuk masalah manajemen. Dalam kebanyakan kasus, rumus matematika dengan bantuan komputer atau prosedur komputasi digunakan dalam pemodelan analisis manajemen.

Teori manajemen telah berfokus pada karakteristik perilaku dan motivasi dalam struktur dan sistem organisasi sejak awal. Lompatan maju dalam hipotesis administrasi ini penting bagi pencetus MIS karena mereka membantu informasi tentang bagaimana kerangka kerja manusia dan mesin bekerja, sama seperti kemajuan model pilihan. Sistem untuk Membuat Keputusan Sistem keputusan, atau model sistem yang digunakan untuk membuat pilihan, bisa tertutup atau terbuka. Sistem pengambilan keputusan yang menganalisis pemisahan keputusan dari input non-keputusan dari sosial. Dalam tatanan dinamis ini diasumsikan bahwa:

1. Ketahui setiap gadget elektif dan semua hasil atau hasil masingmasing.

2. Memiliki strategi (aturan, koneksi, dan sebagainya) yang memungkinkan membuat permintaan signifikansi, semua hal dipertimbangkan.

3. Pilih pilihan yang menambah 
sesuatu, seperti keuntungan, volume transaksi, atau kenyamanan.

$\begin{array}{lrr}\text { Gagasan } & \text { tentang } & \text { kerangka } \\ \text { pilihan } & \text { tertutup } & \text { jelas }\end{array}$
mempertimbangkan individu yang bijaksana yang secara sah menguji semua pilihan lain, menentukan peringkat sesuai dengan pentingnya hasil, dan memilih pilihan yang mendorong hasil terbaik / terbesar. Model kuantitatif dinamis sering kali merupakan model kerangka kerja pilihan tertutup. Pilihan dalam kerangka pilihan terbuka dilihat sebagai lingkungan yang kompleks dan membingungkan. Pilihan dipandang ada dalam iklim yang rumit dan mungkin ambigu dalam kerangka pilihan terbuka.

\section{Chief dipandang tidak} benar-benar masuk akal dan benarbenar waras, namun lebih menunjukkan objektivitas hanya di dalam titik potong yang ditetapkan oleh yayasan, perspektif tentang pilihan lain, kapasitas untuk menangani model pilihan, dan lainnya. Dengan asumsi tujuan dalam model tertutup jelas, tujuan terbuka hampir sama dengan tingkat tujuan karena mereka dapat berubah jika pilihan mengakui bukti atau gagal.

Dikontraskan dan tiga anggapan model tertutup, model pilihan terbuka menerima mengasumsikan:

1. Tidak semua opsi dan konsekuensi tersedia.

2. Pencarian dipersempit menjadi beberapa opsi yang memungkinkan.

3. Buat keputusan yang sesuai dengan tingkat ambisinya.

Model terbuka bersifat dinamis atas permintaan keputusan karena tingkat tujuan berubah sebagai kontras antara hasil dan tingkat keinginan. Teori perilaku pengambilan keputusan memperluas gagasan ini. Penggambaran Dinamis Sebuah model dinamis yang memberitahu kepala suku bagaimana ia harus menyelesaikan kelas pilihan yang dikenal sebagai model regularisasi atau preskriptif. Model deskriptif adalah model yang menggambarkan bagaimana orang benar-benar mengambil keputusan. Ekonom dan ilmuwan manajemen adalah pencipta model normatif yang paling umum. Model normatif meliputi pemrograman linier, teori 
permainan, penganggaran modal, dan teori keputusan statistik.

Karena mereka dikembangkan terutama oleh para ilmuwan perilaku, model deskriptif bertujuan untuk menjelaskan perilaku yang sebenarnya.

4. Peranan SIM dalam Pengambilan Keputusan

$$
\text { Fungsi terpenting }
$$

dari kepemimpinan, pengambilan keputusan, terutama adalah kepemimpinan, dan perhatian serta pemikirannya digunakan untuk memeriksa Proses pengambilan keputusan. Semakin tinggi kepemimpinan organisasi, semakin penting keputusannya. Perilaku dan pengambilan keputusan manajer memiliki pengaruh penting terhadap perilaku dan sikap karyawan. Solusimasalah mengarah pada pengambilan keputusan, dan hasil dari masalah adalah situasi mutlak di mana alternatif yang tersedia dipilih dan masalah atau proses pemikiran yang bermasalah diselesaikan. Pengambilan keputusan mengarah pada dua fungsi memiliki: titik awal dari semua perilaku sadar dan bertujuan individu dalam lembagadan organisasi, baik individu atau kelompok, sadar dan ditargetkan sampai batas tertentu. Dia adalah seorang futuris, yang berarti dia khawatir tentang masa depan (efek atau efek yang bertahan lama). Pengambilan keputusan dengan tujuan tunggal berarti bahwa keputusan akhir terkait dengan satu masalah. Yang mana, Setelah keputusan dibuat, itu tidak ada hubungannya dengan masalah lain, dan ketika solusi akhir berisi banyak masalah, itu akan memiliki tujuan ganda, yang berarti membuat keputusan pada saat yang sama untuk menyelesaikan dua atau lebih masalah yang berkonflik atau berkonflik. Tidak kontradiktif. ...Menurut Syamsi (1995: 13), faktor- faktor berikut harus diperhatikan ketika mengambil keputusan: (1) Tujuan keputusan, d. $\mathrm{H}$ Mengetahui terlebih dahulu tujuan mana yang akan dicapai berdasarkan keputusan tersebut; (2) Mencari alternatif pemecahannya. Pilih pertanyaan untuk membantu Anda mencapai tujuan ini. Anda perlu membuat daftar jenis operasi yang dapat Anda pilih.

(3) Menghitung faktor-faktor yang mungkin tidak diketahui atau tidak 
dapat diakses oleh manusia (kejadian yang tidak dapat dikendalikan); (4) Alat atau alat yang digunakan untuk mengukur atau mengukur. Mereka digunakan untuk mengukur hasil dari suatu keputusan. Elemen keputusan Ini dapat digunakan oleh manajer, dan harus dapat menganalisis dan mempertimbangkan tujuan pengambilan keputusan, identifikasi masalah, faktor internal dan eksternal organisasi / organisasi, dan alat pengambilan keputusan. Menurut Terry (2002): 16), keputusan ini didasarkan pada lima poin berikut:

a. Instuisi (perasaan)

Keputusan berdasarkan intuisi atau persepsi bersifat subjektif dan karenanya rentan terhadap pengaruh. Ada banyak keuntungan dan kerugian membuat keputusan berdasarkan intuisi. Manfaatnya meliputi: waktu yang relatif singkat untuk pengambilan keputusan. Untuk masalah dengan konsekuensi terbatas, keputusannya biasanya memuaskan, Kemampuan pengambil keputusan sangat penting dan perlu digunakan dengan benar. Kerugiannya adalah keputusan akhir relatif buruk, dan alat perbandingan sulit ditemukan. Karena keaslian dan efektivitas sulit diukur, mekanisme pengambilan keputusan lainnya sering diabaikan.

b. Pengalaman

$$
\text { Pengambilan keputusan }
$$

berdasarkan pengalaman memiliki keunggulan dibandingkan pengetahuan praktis karena didasarkan pada pengalaman pribadi. dapat memprediksi hal-hal tertentu dan menghitung kelebihan dan kekurangan serta kelebihan dan kekurangan dari keputusan tersebut. Pengalaman dapat memprediksi masalah, dan bahkan pemindaian cepat dapat menemukan solusi untuk masalah tersebut.

c. Fakta

Fakta Keputusan berdasarkan fakta dapat membantu Anda membuat keputusan yang sehat, bijaksana, dan benar. Fakta dapat meningkatkan kepercayaan pada pengambil keputusan sehingga orang dapat mengambil keputusan dengan cepat dengan tangan terbuka.

d. Wewenang

Keputusan berbasis otoritas biasanya dibuat oleh manajemen untuk bawahan atau bawahan. Ada juga keuntungan dan kerugian 
membuat keputusan berdasarkan izin. Manfaatnya meliputi: Sebagian besar penerimaan bergantung pada apakah penerima bersedia atau dipaksa, keputusan bisa memakan waktu lama, dan memiliki keaslian yang membingungkan.

e. Rasional

\section{Dalam} pengambilan keputusan berdasarkan rasionalitas, maka keputusan akhir bersifat objektif, logis, transparan dan konsisten dengan tujuan untuk memaksimalkan hasil atau nilai dalam batasan tertentu, sehingga dapat dikatakan mendekati fakta atau ekspektasi. Berikut beberapa poinnya: (1) Kejelasan masalah, kurangnya keraguan dan kurangnya pemahaman tentang masalah; (2) Komitmen dan solidaritas dalam memahami tujuan yang ingin dicapai;

(3) Pengetahuan alternatif, segala jenis dan akibatnya dari semua alternatif Semua diketahui; (4) preferensi yang jelas, Substitusi dapat diklasifikasikan menurut standar; (5) Untuk memaksimalkan hasil dan memilih alternatif terbaik berdasarkan hasil ekonomi yang wajar tersebut, terdapat beberapa hal, yaitu: (1) Kejelasan masalah, niscayadan kebingungan masalah. ; (2) Komitmen dan solidaritas dalam memahami tujuan yang ingin dicapai;

(3) Pengetahuan alternatif, semua jenis dan konsekuensi dari semua substitusi diketahui; (4) Preferensi jelas, alternatif dapat diklasifikasikan sesuai standar; (5) hasil maksimal, pemilihan alternatif terbaik didasarkan atas hasil ekonomis yang maksimal. Pengambilan keputusan secara rasional berlaku sepenuhnya dalam keadaan yang ideal.Faktor- faktor yang Mempengaruhi Pengambilan Keputusan Dalam proses pengambilan keputusan, suatu organisasi tidak terlepas dari faktorFaktor yang mempengaruhinya. Faktor-faktor tersebut antara lain:

a. Posisi atau kedudukan

Dalam struktur pengambilan keputusan, jabatan atau jabatan dapat dilihat sebagai: (a) posisi pengambil keputusan, pengambil keputusan atau karyawan; (b) promosi, seperti strategi, kebijakan, regulasi, organisasi atau teknologi.

b. Masalah

Masalah atau masalah 
merupakan halangan untuk mencapai suatu tujuan, yaitu penyimpangan dari ekspektasi, rencana, ekspektasi, atau tujuan yang harus diselesaikan. Ada dua jenis masalah terstruktur dan masalah tidak terstruktur.

c. Situasi

Situasi adalah keseluruhan faktor dalam keadaan uamh berkaitan satu sama lain, dan Yang secara bersamasama memencarkan pengaruh terhadap kita beserta yang hendak Kita perbuat.

d. Kondisi

Kondisi adalah semua faktor yang secara kolektif menentukan tindakan, tindakan, atau kemampuan kami. Sebagian besar faktor ini adalah sumber daya.

e. Tujuan

Tujuan yang ingin dicapai telah ditentukan atau ditentukan, apakah itu tujuan tunggal, tujuan unit, tujuan organisasi atau tujuan bisnis secara keseluruhan. Tujuan yang ditetapkan dalam keputusan adalah tujuan atau sasaran perantara.

6. Jenis-jenis Pengambilan Keputusan Jenis keputusan juga dapat dibuat dari perspektif yang berbeda a. Pengambilan keputusan berdasarkan pengambilan keputusan Umumnya, organisasi memiliki hierarki tata kelola. Hierarki ini dibagi menjadi tiga tingkatan: manajemen tingkat tinggi, manajemen tingkat Pengambilan keputusan berdasarkan aturan manajemen menengah dan bawah Solusi yang diusulkan oleh Simon (1995) dibagi menjadi dua aspek berikut: (1) Pengambilan keputusan yang direncanakan: pengambilan keputusan yang teratur dan berulang. ditentukan melalui tindakan penanggulangan terhadap masalah berikut: - Mengatur prosedur nontindakan (serangkaian langkah terkait dan berurutan yang harus diikuti oleh pembuat keputusan ) perumusan kebijakan), Pedoman ( Pedoman untuk mendefinisikan parameter pengambilan keputusan),

(2) Pengambilan keputusan yang tidak terencana: Membuat keputusan non-standar untuk memecahkan masalah yang tidak terstruktur. Keputusan berdasarkan lingkungan pengambilan keputusan ini dibagi menjadi empat kelompok: 
(1) membuat keputusan dalam kondisi tertentu,

(2) membuat keputusan dalam kondisi tertentu. Risiko;

(3) Pengambilan keputusan dalam kondisi tidak pasti;

(4) Pengambilan keputusan dalam konflik.

Bagi penanggungjawab organisasi, pengambilan keputusan merupakan tugas utama yang perlu dilakukan. Perilaku dan

keputusan eksekutif memiliki pengaruh yang signifikan terhadap perilaku dan sikap karyawan.

Membuat keputusan adalah hasil dari pemecahan masalah, dan jawaban dari masalah adalah hukum situasi, yaitu memilih alternatif dari alternatif yang tersedia dan menyelesaikan proses berpikir tentang masalah tersebut.

\section{METODE PENELITIAN}

\section{Jenis Penelitian}

Penelitian ini menggunakan jenis penelitian pustaka (research library). Ini juga biasa disebut sebagai penelitian sastra. Inilah rangkaian kegiatan yang berkaitan dengan pengumpulan data perpustakaan, membaca dan menulis serta metode pengelolaan materi pada artikel ini. Terdapat beberapa alasan metode penelitian perpustakaan, yaitu sumber data hanya dapat diperoleh dari perpustakaan atau dalam bentuk dokumen lain, seperti B. tertulis, yang dapat diperoleh dari buku, majalah dan karya sastra lainnya. Dalam hal ini, data perpustakaan masih dapat diandalkan untuk menyelesaikan masalah penelitian. Informasi atau data yang dikumpulkan dari orang lain berupa buku, laporan, perpustakaan peneliti dapat terus menggunakan hasil penelitian atau laporan survei.

2. Tahap Penelitian Kepustakaan Tahapan penelitian

bibliografimerupakan tahapan yang harusdilakukan penulis untuk penelitian: mengumpulkan bahan penelitian seperti halnya penelitian kepustakaandalam artikel ini, menampilkan bahan yang dikumpulkan berupa informasi yang diperoleh dari buku, jurnal dan penelitian ilmiah. Laporan penelitian dan materi lain yang mendukung topik tersebut. ... Membaca literatur untuk memasukkan "pengetahuan" ke 
dalam kegiatan "berburu", yang membutuhkan partisipasi aktif pembaca agar memperoleh hasil yangmaksimal.

\section{HASIL DAN PEMBAHASAN}

\section{Konsep Dasar Sistem}

Sistem adalah jaringan proses yang saling berhubungan yang dikelompokkan bersama dan digabungkan untuk melakukan suatu aktivitas atau mencapai tujuan tertentu. Sistem terdiri dari banyak komponen yang saling berinteraksi membentuk satu kesatuan yang koheren. Sebagai alternatif, elemen sistem dapat berupa subsistem atau bagian dari sistem. Setiap subsistem memiliki karakteristik sistem yang menjalankan fungsi tertentu dan mempengaruhi keseluruhan proses sistem Hubungan media antara satu subsistem dengan subsistem lainnya biasanya disebut sambungan (interface). Koneksi,ini

memungkinkan sumber daya mengalir dari satu subsistem ke subsistem lainnya. Ketika keluaran (keluaran) terhubung, subsistem masukan subsistem lainnya (masukan). Setelah terkoneksi, suatu subsistem dapat berinteraksi dengan subsistem lain untuk membentuk suatu kesatuan. Sistem harus mempunyai tujuan atau tujuan. Tujuan dari sistem sangat menentukan masukan dan keluaran yang dibutuhkan oleh sistem. Dihasilkan oleh sistem.

2. Informasi

Data yang sudah diklasifikasi atau diolah atau diinterprestasi buat digunakan Pada proses pengambilan keputusan merupakan liputan. Sistem pengolahan memasak Data sebagai liputan atau tepatnya memasak data menurut bentuk tidak bermanfaat sebagai Bermanfaat bagi penerimanya. Nilai liputan herbi keputusan. Nilai Liputan dilukiskan paling berarti dalam konteks sebuah keputusan. Apabila tidak ada Keputusan, maka informasi menjadi tidak diperlukan. Keputusan sanggup berkisar menurut Keputusan berulang sederhana sampai keputusan strategisjangka panjang.

Fungsi primer fakta merupakan menambah pengetahuan atau mengurangi Ketidak pastian pemakai fakta. Informasi yg disampaikan pada pemakai Mungkin adalah output data yg dimasukkan ke pada \& pengolahan 
suatu Contoh keputusan. Akan tetapi, pada pengambilan keputusan yg kompleks, Fakta hanya bisa menambah kemungkinan keputusan atau mengurangi Beragam pilihan. Informasi yang diberikan kepada pengambil keputusan mengidentifikasi faktor risiko potensial pada tingkat pendapatan yang berbeda. Namun, ketika membuat keputusan yang sulit, informasi hanya meningkatkan kemungkinan pengambilan keputusan, atau mengurangi kemungkinan pilihan. Informasi yang diberikan kepada pengambil keputusan menunjukkan kemungkinan faktor risiko untuk tingkat pendapatan yang berbeda. Informasi (informasi terukur) yang dapat diolah atau dihasilkan dalam fungsi organisasi sangat penting karena sistem informasi menyediakan informasi formal tentang situasi tersebut. yang membuat pengguna lebih mungkin untuk memprediksi peristiwa atau peristiwa.Hasil dari aktivitas organisasi (termasuk aktivitas pengguna itu sendiri). Berdasarkan nilai informasi, aspek-aspek berikut dapat ditentukan: manfaat dan biaya memperoleh informasi ini.

Namun, perlu diingat bahwa informasi yang digunakan untuk tujuan yang berbeda membuat data tertentu menjadi tidak mungkin dan sangat sulit dikaitkan dengan masalah tertentu, karena sebagian besar informasi tersebut tidak digunakan oleh sebagian perusahaan. Jumlah informasi tidak dapat secara akuratdiartikan sebagai nilai uang, tetapi dapat menjelaskan nilaikeefektifannya. Nilai informasi ini didasarkan pada sepuluh (10) karakteristik, yaitu:

a. Mudah diperoleh

Atribut ini menunjukkan kemudahan dan kecepatan pencarian informasi. Kecepatan pengukurannya, misalnya, 1 menit versus 24 jam. Namun, nilai informasi konsumen sulit diukur.

b. Luas dan lengkap

Atribut ini menunjukkan isi pesan secara lengkap. Ini berlaku tidak hanya untuk jumlah informasi, tetapi juga untuk keluaran informasi. Properti ini sangat luas. Sifat itu ambigu dan oleh karena itu sulit diukur.

c. Ketelitian

Atribut terkait dengan sejauh mana 
tidak ada kesalahan dalam keluaran informasi. Ketika sejumlah besar data terlibat, biasanya ada dua jenis kesalahan: kesalahan registrasi dan kesalahan perhitungan.

d. Kecocokan

Atribut ini menunjukkan seberapa dekat informasi yang ditampilkan cocok dengan kebutuhan pengguna. Isi informasi harus terkait dengan masalah langsung. Semua tur lainnya tidak berguna, tetapi persiapannya mahal. Sifat ini sulit diukur.

e. Ketepatan Waktu

Atribut ini dikaitkan dengan waktu yang berlalu, yang kurang dari waktu pencarian informasi, dan pengiriman, pemrosesan, dan panggilan balik laporan kepada pengguna biasanya tepat waktu. Dalam beberapa kasus, peluang dapat diukur.

f. Kejelasan

Atribut ini menunjukkan tingkat keluaran informasi tanpa istilah yang ambigu. Biaya mengoreksi laporan bisa jadi mahal.

g. Keluwesan

Atribut ini terkait dengan adaptasi keluaran informasi, tidak hanya untuk beberapa keputusan, tetapi juga untuk beberapa pembuat keputusan. Properti ini sulit untuk diukur, tetapi dalam banyak kasus, properti ini dapat diberikan nilai yang dapat diukur.

h. Dapat dibuktikan

Atribut ini menunjukkan kemampuan beberapa pengguna informasi untuk melihat keluaran informasi dan mencapai kesimpulan yang sama.

i. Tidak ada prasangka

Sifat ini terkait dengan kurangnya informasi perubahan untuk mendapatkan kesimpulan yang dipertimbangkan sebelumnya.

j. Dapat diukur

Atribut ini menunjukkan jenis informasi yang dihasilkan oleh sistem informasi formal. Nilai ideal informasi adalah bahwa pengambil keputusan dapat memilih solusi terbaik dalam setiap situasi, daripada memilih rata-rata solusi terbaik, dan menghindari peristiwa yang menyebabkan kerugian, tetapi informasi yang akurat mungkin tidak tersedia. Dalam hal ini, estimasi Hasil sebelumnya mungkin dipengaruhi oleh informasi lain. Meskipun informasi ini tidak kredibel, informasi yang tidak lengkap sebenarnya adalahinformasi tentang sampel. Informasi ini tidak 
ideal karena memberikan lebih banyak perkiraan daripada angka tertentu. Kualitas informasi bergantung pada tiga (tiga) faktor: informasi harus benar, mutakhir dan mutakhir.

a. Akurat

Informasi tidak boleh mengandung kesalahan, bias atau menyesatkan. Akurasi juga berarti bahwa informasi harus secara jelas mencerminkan maknanya. Informasi tersebut harus benar, karena mungkin terdapat banyak gangguan (noise) dari sumber informasi kepada penerima informasi, yang dapat mengubah atau merusak informasi tersebut.

b. Tepat waktu

Informasi tersebut tidak boleh terlambat sampai ke penerima. Informasi yang ketinggalan zaman tidak lagi berharga, karena informasi adalah dasar pengambilan keputusan.

c. Relevan

Informasi ini memiliki keuntungan bagi pengguna. Relevansi informasi bervariasi dari satu orang ke orang lain. Misalnya informasi tentang penyebab kegagalan mesin produksi tidak ada sangkut pautnya dengan akuntansi perusahaan, dan lebih relevan saat menghubungi engineerperusahaan.

3. Sistem Informasi Manajemen (SIM)

Sistem Informasi Manajemen (SIM)

adalah jaringan informasi yang dibutuhkan manajer untuk menjalankan fungsinya (untuk kepentingan organisasi), terutama ketika mengambil keputusan untuk mencapai tujuan organisasi. Operasi kontrol. Komputer menambahkan satu atau dua dimensi, seperti Kecepatan, akurasi, dan lebih banyak data dapat membantu Anda mempertimbangkan lebih banyak alternatif dalam solusi yang terdiri dari banyak elemen dalam organisasi, orang-orang dengan peran berbeda dalam organisasi, operasi atau tugas yang perlu dilakukan, Lokasi kerja, referensi kerja dan hubungan komunikasi dengan organisasi. SIM Adalah aplikasi sistem informasi organisasi yang dapat mendukung informasi yang dibutuhkan olehpemerintah di semua tingkatan

Fokus kartu SIM ada pada sistem, SIM tidak dikontrol, tetapi agar berfungsi secara efektif, harus dikelola semaksimal mungkin. Sisteminformasi dapat digambarkan 
sebagai struktur piramida dalam berbagai tahapannya, dan tingkat yang lebih rendah mencakup informasi tentang transaksi. Proses, Ujian negara bagian, dll. Tahap selanjutnya meliputi sumber informasi yang membantu perencanaan taktis dan pengambilan keputusan, sedangkan tahap pertama meliputi sumber informasi yang membantu perencanaan manajemen dan pengambilan keputusan.

Karakteristik SIM:

a. SIM sangat bergantung pada ketersediaan data seluruh perusahaan dan arus informasi yang dimiliki perusahaan.

b. SIM biasanya tidak dapat menganalisis masalahnya.

c. SIM Mempertimbangkan perkembangan organisasi di masa depan, hal ini membutuhkan perencanaan yang sangat cermat dan panjang.

d. SIM biasanya berfokus pada data yang telah atau akan terjadi, bukan data yang akan terjadi.

f. SIM juga berfokus pada data di dalam organisasi dan data di luar organisasi.

g. SIM Karena banyak laporan yang sudah dikemas sebelumnya, seringkali tidak cukup fleksibel. Membantu manajer terstruktur dalam hal tingkat operasional, tingkat kontrol dan rencana manajemen senior.

h. SIM Bertujuan untuk memberikan laporan operasi harian untuk memberikan informasi untuk pengendalian operasi yang lebih baik.

\section{KESIMPULAN}

SIM adalah seperangkat alat informasi yang sangat diperlukan oleh industri kecil/pengusaha kecil untuk mengatasi masalah-masalah yang dihadapi. Bagi masyarakat dengan tingkat ekonomi dan pendidikan rendah atau mereka yang memiliki tingkat ekonomi dan pendidikan tinggi, sistem informasi sangat penting untuk memenuhi kebutuhan dasar sehari-hari di semua bidang kehidupan. Tingkat ekonomi dan pendidikan seseorang. Sangat membutuhkan informasi. Fungsi kepemimpinan dasar bekerja dengan baik jika didukung. Memiliki sistem informasi yang baik. Untuk membuat keputusan 
yang tepat, Anda perlu memahami masalah dan memahami solusi alternatif. ... Informasi yang lebih rinci mengarah ke solusi yang lebih baik. Salah satu fungsi terpenting dari kepemimpinan adalah pengambilan keputusan. Pemimpin memperhatikan pikirannya hampir sepanjang waktu. Ini digunakan untuk mempelajari proses pengambilan keputusan. Semakin tinggi levelnya.

\section{DAFTAR PUSTAKA}

Bambang Tri Cahyono dan Sugiyo Adi, 1983, Manajemen Industri Kecil, Liberty, Yogyakarta.

Gordon B, Davis, 1991, Kerangka Dasar Sistem Informasi Manajemen, Jilid I, Pustaka Binaman Pressindo, Jakarta,

1992 ,

Struktur dan Pengembangan

Sistem Informasi Manajemen,

Jilid I, Pustaka Binaman

Pressindo, Jakarta,

Husein, Fakhiri, dkk. 2002. Sistem Informasi Manajemen. Yogyakarta : Unit Penerbit dan Percetakan AMP YKPN.
John Soeprihanto dan Murti Sunarni, 1993, Pengantar Bisnis

(DasarDasar Ekonomi

Perusahaan), Liberty,

Yogyakarta.

J. Djawil, 1991, Sistem Informasi Manajemen Modern, Edisi 3, Erlangga, Jakarta.

Mc. Leod, Raymond, 1996, Sistem Informasi Manajemen , Penerjemah Hendra Tyas, Prenhallindo, Jakarta.

Rochaety, Eti, dkk. 2008. Sistem Informasi Manajemen Pendidikan. Jakarta : Bumi Aksara

Subari, Tata. 2005. Sistem Informasi Manajemen. Yogyakarta : Penerbit Andi

Syamsi, Ibnu. 2000. Pengambilan Keputusan Sistem Informasi. Jakarta : Bumi Aksara. 